\title{
海学景钼に配盧した海岸保全施設の事例集について Some Examples of Shore Protection Facilities in Harmony with Coastal Scenery
}

In the planning of the shore protection facilities the harmony with the coastal environment should be taken into consideration as well as their protective functions and construction costs. However these points have not been analyzed yet and the data necessary for the planning are inadequate. In this study the examples of the coastal facilities in harmony with coastal scenery were gathered. 70 photos of the facilities were collected from the 68 coasts in Japan. These facilities were classified depending types, such as (1) vertical, mildly sloping and stepped type sea walls or revetments, (2) artificial beaches, (3) groins, (4) headlands, (5) detached breakwaters and (6) artificial reefs. The relation between coastal scenery and shore protection facilities is closely described in each type.

Key words: Shore protection facility, Coastal scenery, Harmony with coastal environment, Photo collection.

\section{1.まえがき}

我が国では、越波や侵食の防止を目的として多くの海岸保全施設が建設されてきた。これらの構造物は厳しい 波浪に対して国土保全上の役割を果たしてきたことは間違いないが、その一方で構造物の建設によって海岸の景 観が損なわれた例あ少なから数にのぼっている。また、近年における国民の生活水準の向上、自由時間の増大、 高歯化の進展に伴う観光レクリエーション需要の高まりやその質的高度化等に対応して、海洋空間の有する高い 価値を活用した海岸整備が望まれている。こうした背景のもとに、従来、防災機能面のみを重視して設計されて きた海岸保全施設についてす、海岸の自然環境や海岸利用に配慮する必要性が高まっており、最近では景観に配 虑した海岸保全施設として、人工リーフや石張式の離岸堤などが採用されるようになってきた。本来、海岸景観 は当該海岸全体を対象として自然環境を良好に保ちつつ計画された保全計画に基づいて創出されるべきすのであ り、個々の海岸保全施設の形状を変えることで良好な海岸景観が創出されると考えることはあまりに短絡的であ る。しかしながら、それですなお個々の施設について種々の工夫を行うことは決して無益なことではないであろ う。しかし、今のところ海岸景観に配慮した海岸保全計画の立案手法はなく、海岸保全施設の整備時における担 当者の判断にまかされているのが現状であって、しかす判断材料が十分でなく、設計に苦労するのが実状であっ た。そこで筆者らは、海岸景観に配虑した海岸保全施設を計画する際の基礎資料を得るために、海岸景観に配慮 して建設された海岸構造物の写真を収集し、構造物の種類や海岸の自然条件の観点からそれらの分類整理を試み、 土木研究所資料としてとりまとめを図った(宇多・伊藤，1992）。この調查では全国68海岸における70例の海岸保 全施設の事例が収集された。海岸保全施設に関しては、直立・傾斜型の堤防・護岸、階段式・緩傾斜式の堤防・ 護岸、堤防・護岸の付帯施設（昇降路・階段工）、人工海浜、突堤・人工岬、離岸堤、人工リーフに分類し、各 海岸保全施設ごとに太平洋沿岸、日本海沿岸、瀬戸内海沿岸、東シナ海沿岸の順に北から南へ向かって海岸番号 を付した。各施設ごとの対象事例は表ー1に示す通りであり、それぞれの事例について1対象海岸の位置・海岸 特性、(2)海岸保全施設の建設経緯、(3)景観上の配慮事項等について記述した。ここでは、これらの中から特に13 の事例を選び、これらを紹介するととむに、海岸景観に関して若干の考察を加えた。

\footnotetext{
* 正会員 建設省土木研究所河川研究室長

** 正会員 建設省土木研究所海岸研究室
} 
表- 1 対象海岸

直立・傾斜型の堤防・護岸

\begin{tabular}{|c|c|c|c|}
\hline 太平洋沿岸 & 日本海沿岸 & 瀬戸内海沿岸 & 東シナ海沿岸 \\
\hline $\begin{array}{ll}1 & \text { 福島県大浜海宸 } \\
2 & \text { 葉罩前原海岸 } \\
3 & \text { 東京都横間ヶ浦海岸 } \\
4 & \text { 神萘川県藤沢海岸 } \\
5 & \text { 三重県長島地区海岸 }\end{array}$ & $\begin{array}{l}6 \text { 福井県安島海崖 } \\
7 \text { 福开罧大浜海岸 }\end{array}$ & 8 大分県国東海岸 & 9 佐賀県有明海岸 \\
\hline
\end{tabular}

階段式・緩傾斜式の堤防護岸

\begin{tabular}{|c|c|c|c|}
\hline 太平洋沿岸 & 日本海沿岸 & 瀬戸内海沿岸 & 東シナ海沿岸 \\
\hline 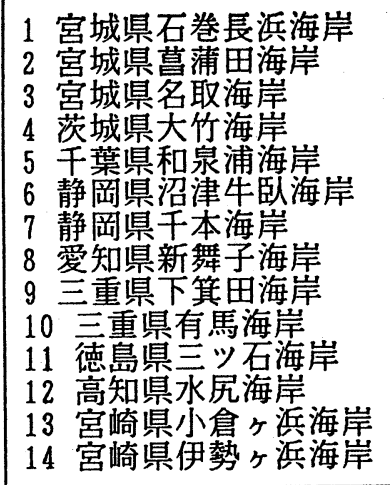 & 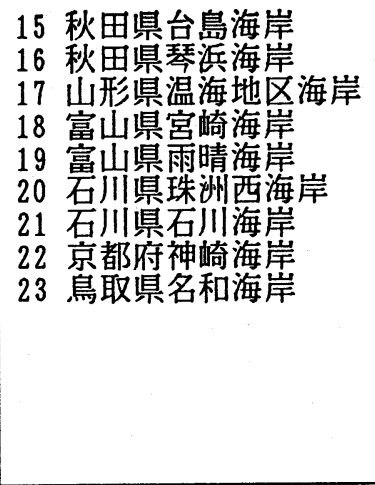 & 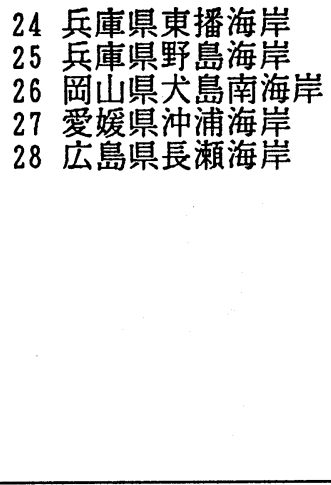 & $\begin{array}{l}29 \text { 熊本県下津汀海岸 } \\
30 \text { 沖縄県北前海岸 }\end{array}$ \\
\hline
\end{tabular}

堤防・護岸の付帯施設（昇降路・階段工）

\begin{tabular}{|c|c|c|c|}
\hline 太平洋沿岸 & 日本海沿岸 & 瀬戸内海沿岸 & 東シナ海沿岸 \\
\hline 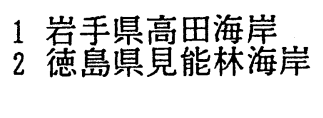 & $\begin{array}{l}3 \text { 北海道浜中海岸 } \\
4 \text { 山形県湯野浜海岸 } \\
5 \text { 石川県三崎海岸 }\end{array}$ & & \\
\hline
\end{tabular}

人工海浜

\begin{tabular}{|c|c|c|c|}
\hline 太平洋沿岸 & 日本海沿岸 & 瀬戸内海沿岸 & 東シナ海沿岸 \\
\hline$\cdot$ & & 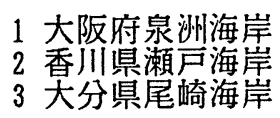 & $\begin{array}{l}4 \text { 佐賀県波戸海崖 } \\
5 \text { 佐賀県満越海 }\end{array}$ \\
\hline
\end{tabular}

突堤・人工岬 (ヘッドランド)

\begin{tabular}{|c|c|c|c|}
\hline 太平洋沿岸 & 日本海沿岸 & 瀬戸内海沿岸 & 東シナ海沿岸 \\
\hline 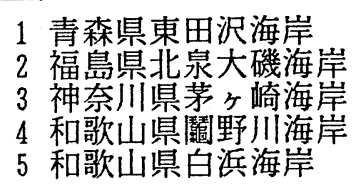 & $\begin{array}{l}6 \text { 富山県小境海岸 } \\
7 \text { 都府浅茂川海岸 }\end{array}$ & 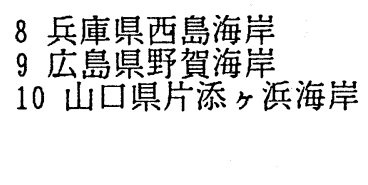 & 11 沖縄県宇地泊海岸 \\
\hline
\end{tabular}

離岸堤

\begin{tabular}{|c|c|c|c|}
\hline 太平洋沿岸 & 日本海沿岸 & 瀬戸内海沿岸 & 東シナ海沿岸 \\
\hline 1 千葉県片貝海宸 & 3 石川県石川海岸 & 4 香川県中谷海岸 & 5 長崎県年崎海岸 \\
\hline 沖縄県東海岸
\end{tabular}

人エリーフ

\begin{tabular}{|c|c|c|c|}
\hline 太平洋沿岸 & 日本海沿岸 & 瀬戸内海沿岸 & 東シナ海沿岸 \\
\hline 1 茨城県高戸海宸 & 3 新潟県碁石海岸 & & 4 鹿児島県長崎鼻海岸 \\
\hline
\end{tabular}


2 . 海岸景観に配慮した海岸保全施設の事例

(1) 神奈川県藤沢海岸 (写真 -1$)$

江の島の対岸に位置しており、国道134号線の拡幅計 画に伴い、波のうちあげ高の低減、海浜へのアクセスの 改善を目ざして、老朽化した既設護岸の前面に展望スペ 一スをむつ階段工が設置された。歩道を兼ねた水吒きに タイルを張るとともに、階段部分に木製のベンチを埋め 込むなど、海岸利用面だけでなく景観面にす配慮がなさ れている。

\section{（2）大分県国東海岸（写真-2）}

大分県杵築市に位置し、県下随一の海水浴場となって いる。護岸の天端には砂利を埋め込んだタイルが用いら れ、防護栅には擬木が使用されるなど、前面の白砂や背 後の松林之調和した景観が作られるよう配虑されている。 特に、この海岸では護岸前面の前浜が十分広く、護岸は 控え目な印象を与えることが注目される。

\section{（3）宮崎県伊勢ヶ浜海岸（写真一3）}

当海岸は小さな岬に囲まれた砂浜海岸であり、海水浴 などのレクリェーションの場として親しまれている。ま た、周辺は日豊海岸国定公園に指定された景勝地である。 周辺環境および海浜利用に配慮して階段護岸が施された が、単一ブロックによる施工とせず、擬石平板を使用す る区間と、擬木に洗い出し平板を使用する区間を併用し、 護岸の外観に変化が付けられた。

\section{(4) 秋田県台島海岸 (写真 -4$)$}

当海岸は男鹿国定公園内に位置する岩礁海岸で、夏期 には絶好の海水浴場としてにぎわう。背後が道路と して使用されていることや、浜辺がほとんどないことな どから、比較的幅の広いブロックによる階段式護岸が整 備され、安全で快適な親水空間の創出が図られた。また 景観面にむ配慮し、護岸と白い岩が一体となって 背後の緑や海の青とのコントラストが映えるような工夫 がなされている。

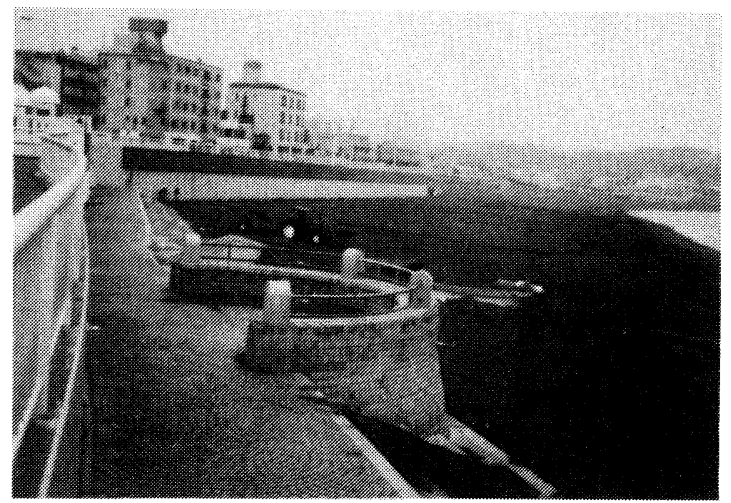

写真 -1 神奈川県藤沢海岸

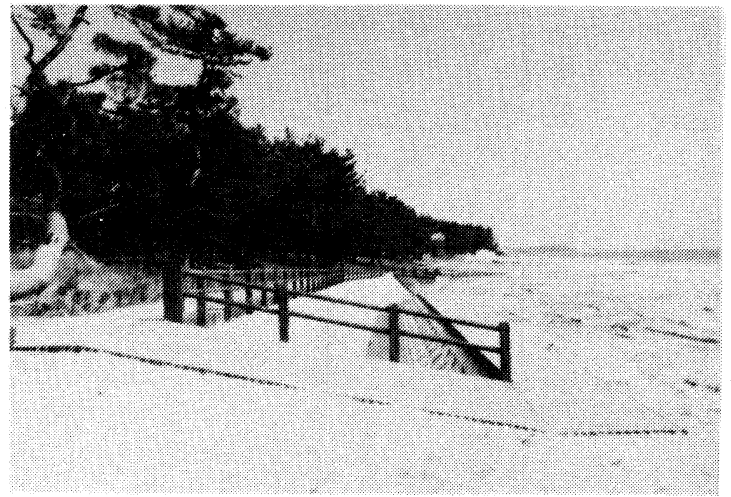

写真-2 大分県国東海岸

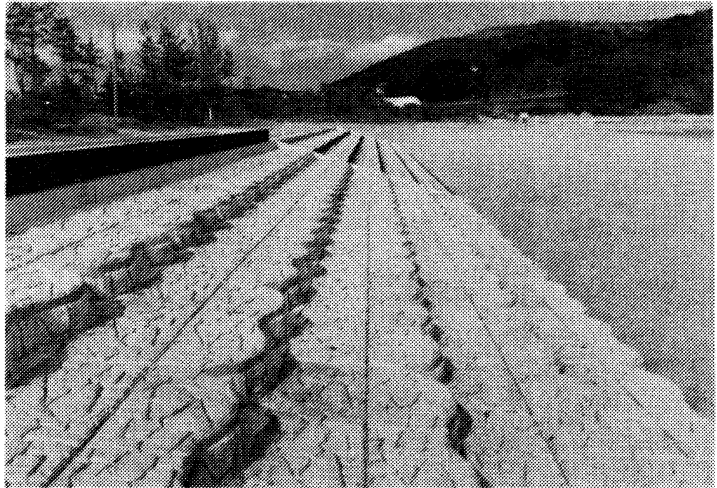

写真 -3 宮崎県伊勢ヶ浜海岸

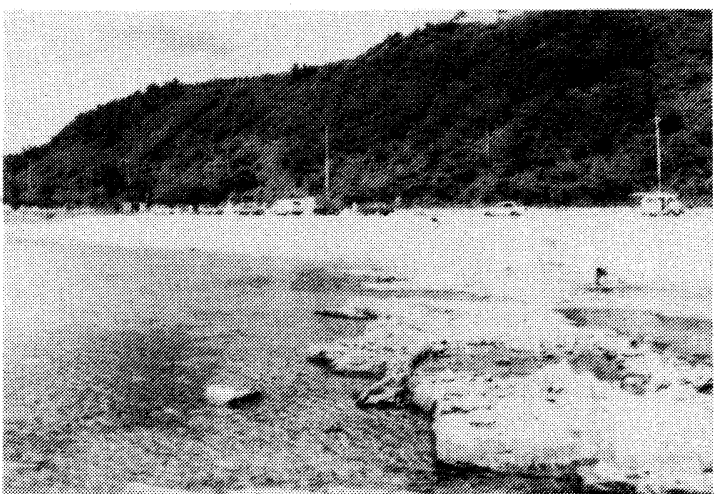

写真-4 秋田県台島海岸 
(5)広島県長瀬海岸 (写真 - 5)

当海岸は西能美島の南部江田島湾に位置している。 付近一帯は瀬戸内海国立公園の指定を受けた多島海の風 光明媚な景勝地である。ここでは海洋性レクリェーショ ン基地としての整備が進められており、階段護岸に曲線 が取り入れられるなど、海洋利用空間として快適な景観 をむつように配虑されている。自然石を用いた突堤の天 端にカラフルな遊歩道が設置されるなど、自然と人工構 造物の調和を図るような工夫すなされている。

(6)熊本県下津江海岸 (写真-6)

島原湾の奥、早崎瀬戸の近くにある天草郡上島に位置 する海岸である。表面に御影石を張ったブロックや自然 石を用いて緩傾斜堤を建設することにより周囲の自然景 観との調和を図り、円抔状にブロックを配置することに より幾何学的にきれいな法線が形成された。

(7)沖縄県北前海岸 (写真 -7$)$

当海岸は沖縄本島の西海岸に面し、天然リーフが発達 している。21世紀を展望した町づくりのために、沖縄で 最す重要な地域として位置付けられている。背後地の安 全を確保するとともに、周囲の自然景観や観光地として の景観保護に配慮がなされた。緩傾斜堤の表のりは約50 $0 \mathrm{~kg}$ の琉球石灰岩で被覆され、天端はカラー舗装が施さ れて遊歩道としての機能す持たされた。

\section{(8)山形県湯野浜地区海岸 (写真-8)}

山形県鶴岡市に位置し、日本海に面している。海岸沿 いには主要地方道である酒田温海線が走っており、その 背後に湯野浜温泉街が広がっている。この道路は幅員が 狭く歩道むなかったため、海水浴シーズンには歩行者や 車両が錯綜して危険であった。そこで、直立護岸を設置 するととむに、天端上に快適で優れた景観を持った利用 空間を創出するために遊歩道を兼ねる水吒き、植栽スペ 一ス、幅広い砂浜に見合った勾配の緩い円形階段が設置 された。アクセスや景観上より多くの工夫がなされたが、 最近では飛砂による過剩な土砂堆積が問題化しつつある。

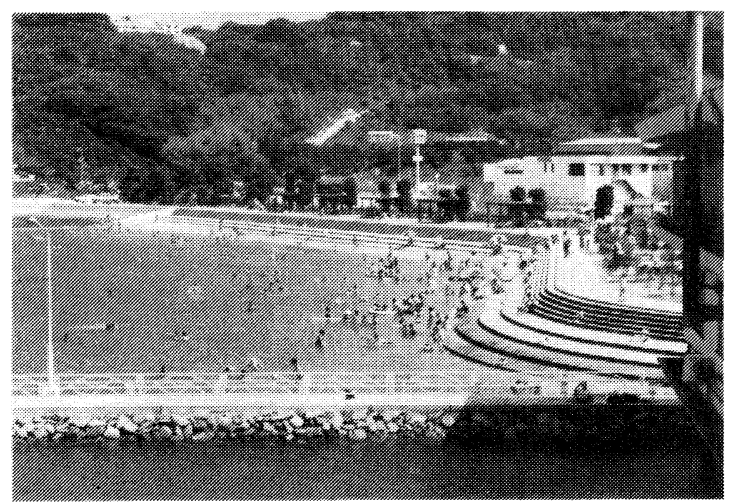

写真 -5 広島県長瀬海岸

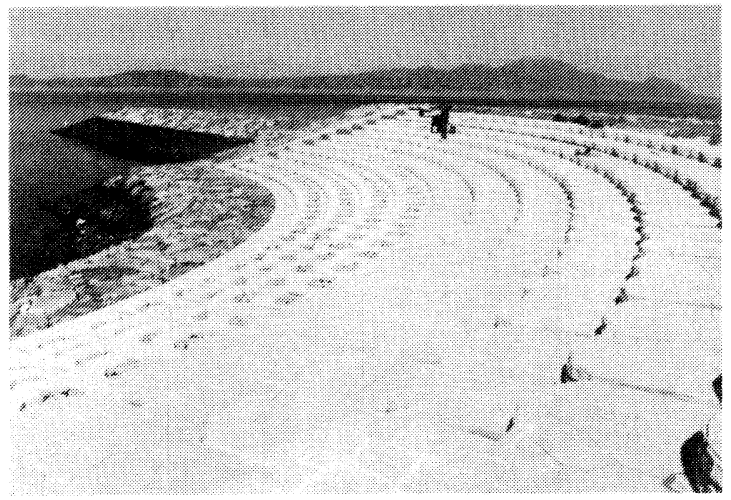

写真 -6 熊本県下津江海岸

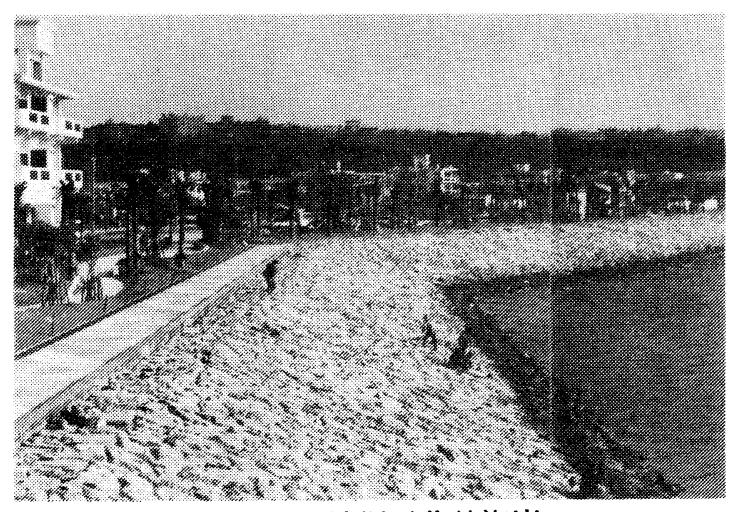

写真 -7 沖縄県北前海岸

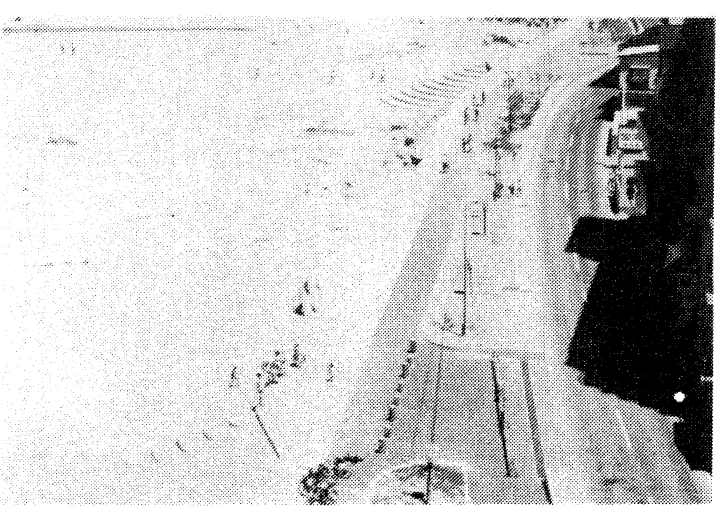

写真-8 山形県湯野浜地区海岸 
(9)佐賀県波戸海岸 (写真-9)

玄海国定公園の利用拠点となっている波戸岬に位置し、 各種のレクリェーション施設の整備が進んでいる。しか し、公園内で唯一砂浜のある波戸海岸で海岸侵食が進み、 砂浜の消失が危惧されたため、砂浜を回復し、海洋性レ クリェーションの場を確保するために、比較的静穏な西 側の海岸を対象に養浜が実施された。自然海浜の消波機 能を活かし、できるだけ自然に近い形での環境整備が行 われた例である。

(10) 青森県東田沢海岸 (写真-10)

陸奥湾の湾奥に位置し、浅虫夏泊県立自然公園内とい う恵まれた環境にあることから、周辺の自然景観に溶け 込むような海岸整備が行われた。緩傾斜堤の法線は海岸 線に合わせた曲線形とし、突堤は極力自然石を用いて造 られた。突堤と緩傾斜堤の曲線が美しい幾何学的輪郭を 形成している。滑らかな構造物形状はデザイン的には良 好であるが、この海岸は陸奥湾の中にあるため波浪が小 さく、突堤間の海水が滞留し易いのが難点である。 (11) 沖縄県宇地泊海岸 (写真-11)

沖縄県都那異市近郊にあり、同県の中心部近くに位置 している。海岸の背後には宜野湾海浜公園、コンベンショ ンホール、マリーナ等が整備されており、これらと合わ せて、ピクニックや海辺との触れあいができる中央突堤 をべースにした人工ビーチが形成された。ヘッドランド 周辺のブロックが人工的ではあるものの、ヘッドランド を曲線形で形取り、堆砂機能の向上と汀線形との調和が 期待されている。

(12) 香川県中谷海岸 (写真 -12 )

香川県に位置し、周辺に点在する多くの小島とともに、 瀬戸内海特有の景観を呈している。陸側のり面を自然石 張りにすることにより、離岸堤は修景を施されており、 陸側からの眺望に対して周辺の自然景観との調和が図ら れている。

(13) 茨城県高戸海岸 (写真 -13$)$

太平洋に面した茨城県の高萩市に位置するポケットビ 一チである。C.C.Z計画による背後地の整備計画、マ リーナ建設計画と合わせて、砂浜幅を広げ、静穩域を確 保する海岸保全施設が望まれた。独特な崖と周囲の松が 美しい自然景観を生み出しており、これを阻害しない人 エリーフが採択された。
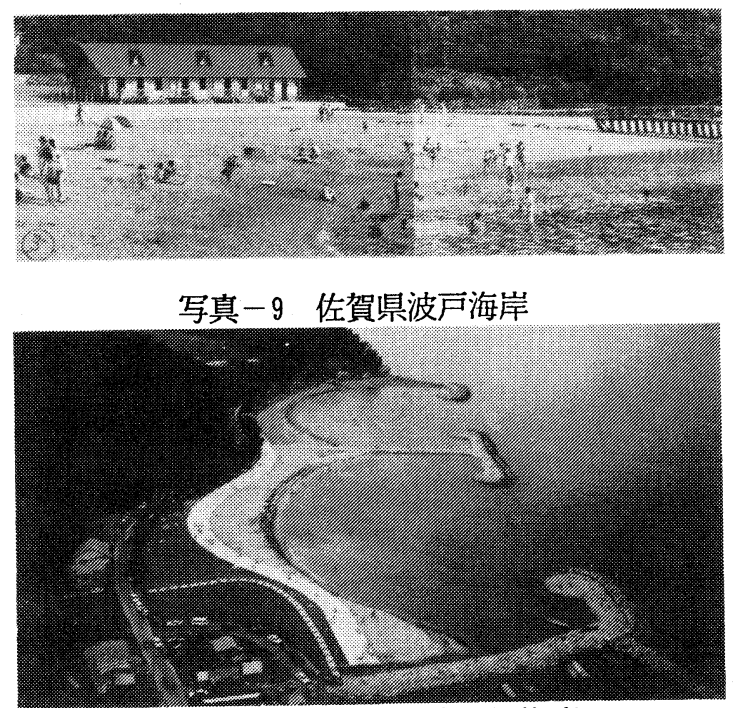

写真-10 青森県東田沢海岸

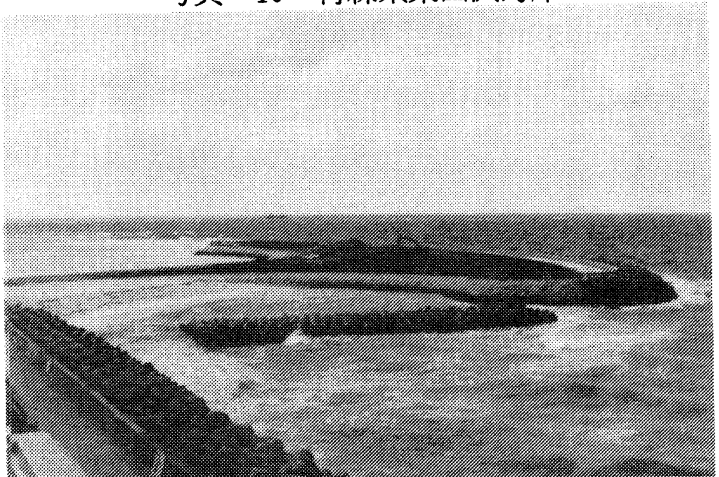

写真-11 沖縄県宇地泊海岸

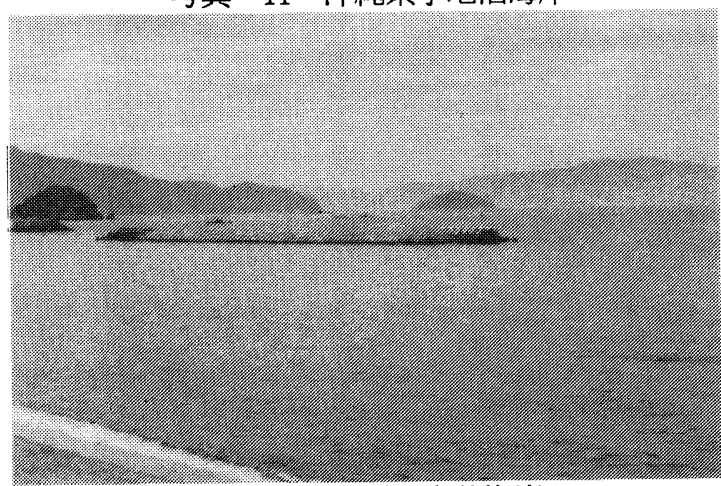

写真 -12 香川県中谷海岸

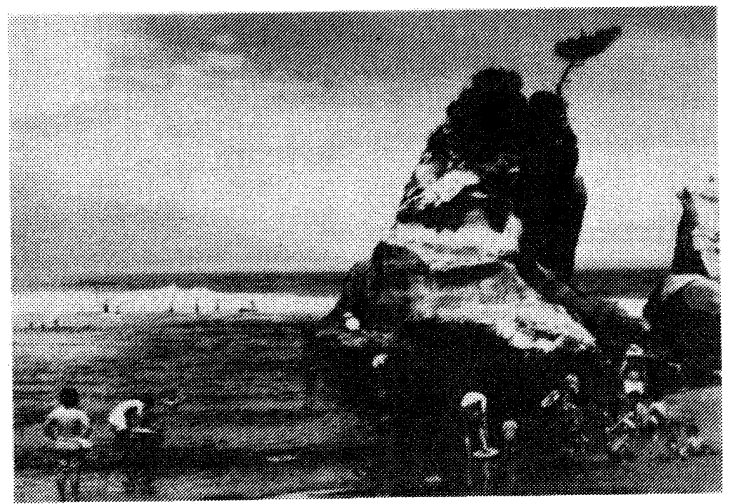

写真 -13 茨城県高戸海岸 


\section{3. 海岸景観に関する考察}

前節では、海岸景観との調和を考えて設計された保全 施設の事例を紹介した。実際の設計においては、これら の事例を単に模做するのでは不十分であり、その海岸の 周辺の自然条件や景観などについて十分考察することが 必要とされる。一例として、写真一14に示す東播海岸の 江井ヶ島地区の人工海浜の景観について考える。ここで は、景観に配慮した越波対策として階段式護岸とその前 面に人工海浜が造られ、さらには護岸の天端上に植栽が 施された。現在、海浜は海水浴場や海辺の您いの場とし て利用されており、景観についてもかなり高い評価を得 ている。海浜は両端を突堤（間隔約 $150 \mathrm{~m}$ ）により、ま た背後は階段式護岸で囲まれており、砂浜幅は約 $50 \mathrm{~m}$ あるため、海岸の風景が比較的狭い視野に納まるのが特 徵である。

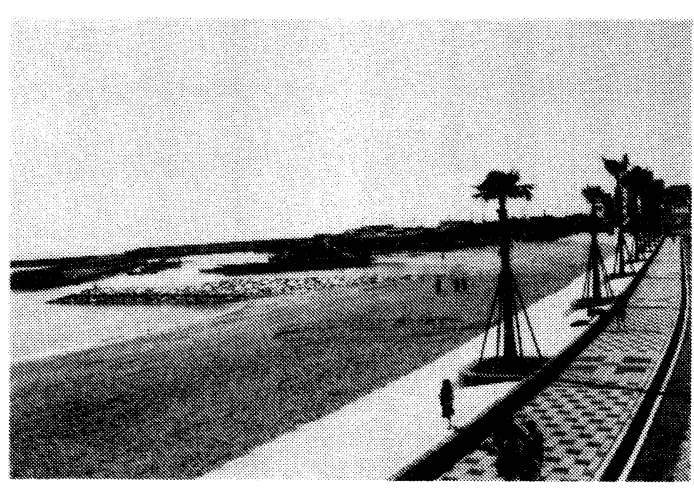

写真 -14 兵庫県東播海岸

このような箱庭的風景は我が国では実は長い歴史を持つものである。例えば、写真-15には京都の近郊、山科 の小野の里にある随心院の庭園を示すが、写真一14に示す景観設計の深層にはこのような風景を望ましいむのと のする思想が流れているように思われる。これは確かに一つの方向ではあるが、自然の砂浜、例えば去から言わ れてきている白砂青松の風景はより広い目由空間を感じさせるものであったはずである。これは例えば庭園では、 京都竜安寺の石庭（写真-16）を想起させる。この写真では左右は無限に続くイメージを有しており、沿岸方向 の広がりを感じさせる。これらのことを考慮すると、今後の人工海浜の設計においては、養浜砂の流出防止にあ まり強く拘でいすることなしに、より長く、広々とした海岸線をむつ海浜へと設計思想を広げていく必要がある と考える。

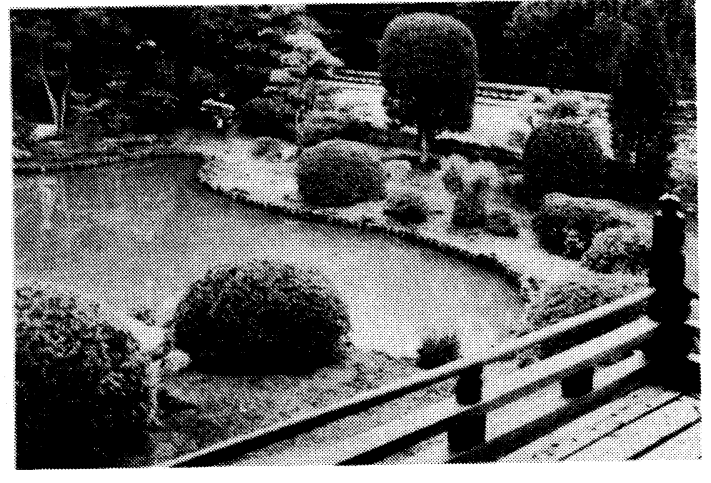

写真 -15 京都府山科の随心院の庭園

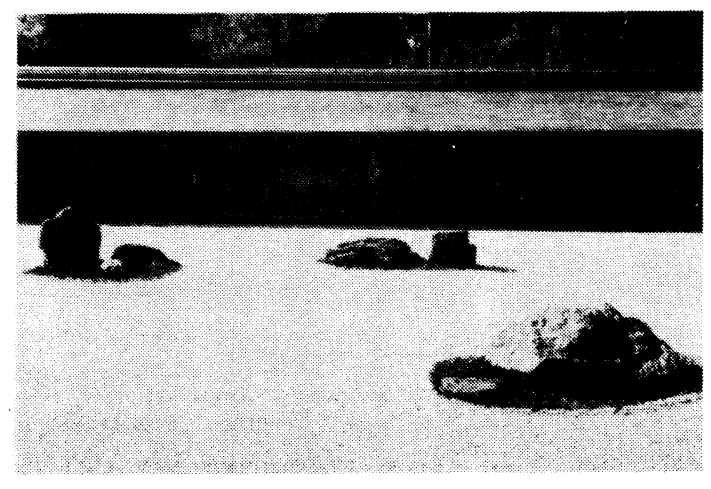

写真-16 京都竜安寺の石庭

\section{4.まとめ}

いずれも多くの制約条件の中で施設の計画が進められているために、海岸環境を劇的に改善することはできな いあのの、それであ多少の工夫により環境がかなり改善された例が見られる。こうした例を知っておくことは、 今後同様な検討を行おうとする海岸です多少役立つと思われることから、本資料が今後有効に利用されることを 願うあのである。また、海岸では高波浪の作用をしばしば受けるから、単に見かけのよいすのを造ってあ波の作 用でただちに被災する危険性を有している。特に、従来からある砂浜に構造物を出しゃばって造ったときそのよ うな結果に終わることが多い、この点が河川での同種の工事と最も違う点である。構造物はできるだけ控え目に 作り、無理をしないことが肝要である。また、今後の良好な海岸景観としては、箱庭的風景よりあ、長い海岸線 をすった自然の砂浜に近いものを開発目標とすることが望ましいことを述べた。

\section{参考文献}

宇多高明・伊藤弘之(1992）：海岸景観に配慮した海岸保全施設の事例集，土木研究所資料, 第3138号，26p. 